\title{
PENGARUH MODEL PEMBELAJARAN KOOPERATIF TIPE GROUP INVESTIGATION BERBANTUAN MEDIA QUESTION CARD TERHADAP SIKAP SOSIAL DAN HASIL BELAJAR PKN
}

\author{
Redy Kresna Arimbawa ${ }^{1}$, Ndara Tanggu Renda ${ }^{2}$, Dewa Nyoman Sudana ${ }^{3}$ \\ Prodi Pendidikan Dasar, Universitas Pendidikan Ganesha, Singaraja, \\ e-mail: redykresna12@gmail.com ${ }^{1}$, tanggurenda@yahoo.com ${ }^{2}$, dewanyoman.sudana@undiksha.ac.id ${ }^{3}$
}

\begin{abstract}
Abstrak
Permasalahan dalam penelitian ini adalah rendahnya sikap sosial siswa yang mempengaruhi hasil belajar siswa dan akhirnya hasil belajar siswa tidak mencapai KKM. Penelitian ini bertujuan untuk mengetahui pengaruh model pembelajaran group investigation berbantuan media question card terhadap sikap sosial dan hasil belajar PKn siswa kelas V SD. Penelitian ini merupakan penelitian eksperimen semu menggunakan rancangan non-equivalent post-test only control group design. Populasi dalam penelitian ini adalah seluruh siswa kelas V SD Gugus VI Kecamatan Negara yang terdiri dari 10 kelas dengan jumlah 205 siswa. Setelah dilakukan uji kesetaraan selanjutnya ditentukan sampel dengan menggunakan Teknik random sampling dan dididapatkan 2 sekolah dengan jumlah 55 siswa yang terdiri dari SD Negeri 2 Kaliakah menjadi kelompok eksperimen dengan jumlah 32 siswa dan SD Negeri 5 Berangbang sebagai kelompok kontrol dengan jumlah 23 siswa. Metode pengumpulan data dalam penelitian ini menggunakan metode non test dan test. Metode non test menggunakan instrument kuesioner sikap sosial dan metode test menggunakan instrumen tes hasil belajar PKn dalam bentuk pilihan ganda. Teknik analisis data yang digunakan adalah analisis statistik deskriptif dan analisis statistik inferensial (MANOVA). Adapun rata-rata skor sikap sosial siswa di kelas eksperimen adalah 111,16 berada pada kategori baik dan di kelas kontrol 89,96 berada pada kategori cukup sedangkan, rata-rata hasil belajar PKn siswa di kelas eksperimen adalah 24,5 berada pada kategori sangat baik dan di kelas kontrol 16,43 berada pada kategori cukup. Hasil penelitian ini dikuatkan berdasarkan perhitungan uji MANOVA yang memperoleh hasil $\mathrm{F}$ pada hipotesis I sebesar 48,229, F pada hipotesis II sebesar 85,807 , dan F pada hipotesis III sebesar 2793,959 yang seluruhnya memiliki Signifikansi sebesar 0,000 yang berarti lebih kecil dari $0,05(0,000<0,05)$. Berdasarkan hasil pengujian hipotesis dapat disimpulkan bahwa terdapat pengaruh yang signifikan model pembelajaran group investigation berbantuan media question card terhadap sikap sosial dan hasil belajar PKn siswa kelas V SD Gugus VI Kecamatan Negara Tahun Pelajaran 2018/2019.
\end{abstract}

Kata kunci: group investigation, hasil belajar PKn, sikap sosial, question card

\begin{abstract}
This research was talked about the lowness of students' social attitude which affect their learning accomplishment in which students' could not reach the learning standard or KKM. The aim of this study was to investigate the effect of group investigation technique by using question card in order to know students' social attitude and the learning outcome of the fifth grade students in learning PKN. This study was a quasi-experimental design which used non-equivalent post-test only control group design. The population used in this study was the fifth grade students of Group VI in Negara district, which consist of ten classes with the total number of the students was 205 students. Moreover, the equivalent test was carried out which then used to determine the sample in this study. By usinh simple random sampling technique, it was determine that there are two school was chosed which was SDN 2 Kaliakah with 55 students as an experimental group and the control group was SDN 5 Berangbang with 32 students. In this study, the data were collected by using non-test and test-method. The instrument used in non-test model was questionnaire of students' social attitude and the result of PKN objective test used as the instrument of test-method. The data was analysed by using descriptive statistics and inferential statistics (MANOVA). The result showed that the average score of students' social attitude in experiment group was 111,6 which categorised
\end{abstract}


as good and the control group gained 89.96 which categorised as adequate. Meanwhile, the result of PKN objective test showed that the average score of experiment group was 24,5 which categorised as excellent, and the control group obtained 16.43 which was also categorised as adequate. These results was supported by the used of MANOVA test in which the $F$ result to hypotheses I was 48.229, and the $F$ result of hypotheses II obtained 85,807 , and $F$ result in hypotheses III was 2793,959 with the total significant 0.000 which mean it was smallest than $0.05(0.000<0.05)$. Based on hypotheses test, it could be inffered that there was a significant difference of the used group investigation technique by using question card as the learning model toward students' social attitude and learning outcome in PKN subjects on the fifth grade students' SD Gugus (Group) VI in Negara district in year 2018/2019.

Keywords: group investigation, PKN learning outcome, question card, social attitude

\section{Pendahuluan}

Sumber daya manusia yang berkualitas merupakan tumpuan utama agar bangsa Indonesia dapat melaksanakan pembangunan dan mampu bersaing dengan bangsa lain di era globalisasi ini. Pendidikan memiliki peran penting dalam menghasilkan sumber daya manusia yang unggul dan cerdas.

Sejalan dalam Undang-undang tentang fungsi dan tujuan Pendidikan Nasional (Pasal 3 UU RI NO.20 TH. 2003) menuliskan:Pendidikan nasional berfungsi mengembangkan kemampuan dan membentuk watak serta peradaban bangsa yang bermartabat dalam rangka mencerdaskan kehidupan bangsa, bertujuan untuk berkembangnya potensi peserta didik agar menjadi manusia yang beriman dan bertaqwa kepada Tuhan Yang Maha Esa, berakhlak mulia, sehat, berilmu, cakap, kreatif, mandiri, dan menjadi warga negara yang demokratis serta bertanggung jawab.

Tercapainya tujuan pendidikan harus didukung dengan berbagai usaha. Salah satu usaha yang dilakukan pemerintah untuk mencapai tujuan pendidikan nasional dengan melakukan perbaikan kurikulum. Kurikulum merupakan jalan untuk mencapai tujuan pendidikan nasional. Sesuai dengan UU NO 20 TH 2003 Pasal 1 ayat 19, "Kurikulum adalah seperangkat rencana dan pengaturan mengenai tujuan, isi, dan bahan pelajaran serta cara yang digunakan sebagai pedoman penyelenggaraaan kegiatan pembelajaran untuk mencapai tujuan pendidikan tertentu".

Untuk mencapai tujuan pendidikan nasional. maka diberikan mata pelajaran-mata pelajaran seperti yang ditetapkan pada pasal 37 ayar 1 tentang Sistem Pendidikan Nasional, salah satu mata pelajaran yang wajib diajarkan di sekolah dasar adalah mata pelajaran PKn. Renda \& Eka Widiastini (2017:5-6) menyatakan, PKn adalah usaha sadar dan terencana dalam proses pembelajaran agar peserta didik secara aktif mengembangkan potensi dirinya untuk memiliki kecerdasan, kecakapan, keterampilan serta kesadaran tentang hak dan kewajiban sebagai warga negara, penghargaan terhadap hak-hak asasi manusia, kemajemukan bangsa, pelestarian lingkungan hidup, kesetaraan gender, demokrasi, tanggung jawab sosial, ketaatan pada hukum, serta ikut berperan dalam percantuman global.

Dalam peraturan Menteri Pendidikan Nasional (Permendiknas) Republik Indonesia No.22 tahun 2006 tentang Standar Isi, dinyatakan bahwa tujuan PKn adalah agar siswa memiliki kemampuan berpikir kritis, rasional, tanggap dalam menanggapi isu kewarganegaraan, berpartisipasi secara aktif dan bertanggung jawab dan bertindak secara cerdas dalam kegiatan bermasyarakat, berbangsa dan bernegara serta anti korupsi, berkembang secara positif dan demokratis untuk membentuk diri berdasarkan karakterkarakter masyarakat Indonesia agar dapat hidup bersama dengan bangsa-bangsa lainnya, serta dapat berinteraksi dengan bangsa-bangsa lain dalam peraturan dunia secara langsung atau tidak langsung dengan memanfaatkan teknologi Informasi dan komunikasi. 
Dalam kenyataannya tujuan PKn seperti di atas belum terlaksana secara maksimal dalam pembelajaran. Hal ini dialami oleh SD Gugus VI Kecamatan Negara yang dapat dibuktikan berdasarkan hasil wawancara, observasi dan studi dokumen. Dari kegiatan tersebut diperoleh informasi mengenai beberapa permasalahan pembelajaran pada mata pelajaran PKn. Adapun hasil dari wawancara dengan guru-guru mata pelajaran PKn kelas $\mathrm{V}$ di Gugus VI Kecamatan Negara pada tanggal 13 Desember 2018 yaitu, 1) siswa masih pasif dalam pembelajaran PKn, 2) siswa cenderung bosan dikarenakan luasnya materi PKn yang harus dipahami, 3) Tidak adanya media pembelajaran di sekolah untuk membantu guru dalam menjelasakan materi, 4) siswa cenderung egois dalam pembelajaran kelompok, 5) hasil belajar siswa masih banyak dibawah KKM.

Adapaun fakta yang diperoleh ketika dilakukan observasi terkait pembelajaran PKn pada tanggal 14 Desember 2018 pada kelas V SD di Gugus VI Kecamatan Negara dan hasil observasi yang didapatkan ketika melakukan observasi yaitu,

1) Siswa masih cenderung pasif dalam pembelajaran PKn dikarenakan guru sering menggunakan metode ceramah dalam menjelaskan materi yang menyebabkan keaktifan siswa kurang dalam pembelajaran. Selain itu ketika guru menyampaikan materi pembelajaran siswa hanya diminta mencatat apa yang disampaikan guru tanpa memahami materi yang disampaikan.

2) Siswa cenderung bosan dalam pembelajaran PKn. Selain itu cara guru mengajar kurang menyenangkan dan inovatif yang menyebabkan tidak adanya motivasi dan semangat siswa dalam mengikuti pembelajaran.

3) Dalam proses pembelajaran guru tidak menggunakan media dalam menjelaskan materi, sehingga siswa sulit untuk memahami materi yang disampaikan, sehingga menyebabkan proses pembelajaran menjadi kurang aktif, kurang menyenangkan dan kurang menarik.

4) Pada saat pembelajaran kelompok, siswa tidak dapat bekerja sama dengan baik, siswa yang memiliki pengetahuan lebih hanya ingin mengerjakan tugas kelompok secara individu dan saat pembentukan kelompok, siswa cenderung memilih-milih teman. Selain itu siawa kurang disiplin saat pembelajaran berlangsung. Siswa asik berbicara dengan temannya ketika guru sedang menjelaskan materi di depan kelas.

5) Hasil belajar siswa masih banyak di bawah KKM dilihat dari saat kegiatan evaluasi diakhir pelajaran, nilai siswa masih banyak di bawah KKM dikarenakan siswa kurang memperhatikan dan memahami materi yang disampaikan oleh guru, selain itu disebabkan karena guru dalam mengajar kurang inovatif dan tidak ada media yang memudahkan siswa untuk memahami materi yang disampaikan guru.

Hasil wawancara dan observasi tersebut diperkuat dengan hasil pencatatan dokumen yang dilakukan pada tanggal 14 Desember 2018 untuk mengetahui hasil belajar PKn pada siswa kelas V SD di Gugus VI Kecamatan Negara. Adapun hasil studi dokumen seperti pada Tabel 1.

Tabel 1

Nilai Rata-Rata Hasil Belajar PKn Pada Siswa Kelas V Gugus VI Kecamatan Negara

\begin{tabular}{|c|c|c|c|c|c|c|c|}
\hline \multirow[t]{2}{*}{ Nama Sekolah } & \multirow[t]{2}{*}{$\begin{array}{l}\text { Rata-Rata } \\
\text { UAS }\end{array}$} & \multirow[t]{2}{*}{ KKM } & \multirow[t]{2}{*}{$\begin{array}{l}\text { Jumlah } \\
\text { Siswa }\end{array}$} & \multicolumn{2}{|c|}{$\begin{array}{c}\text { Siswa yang } \\
\text { mencapai KKM }\end{array}$} & \multicolumn{2}{|c|}{$\begin{array}{c}\text { Siswa yang } \\
\text { belum mencapai } \\
\text { KKM }\end{array}$} \\
\hline & & & & siswa & $\%$ & Siswa & $\%$ \\
\hline SD Negeri 1 Berangbang & 50,25 & 70 & 16 & 2 & 13 & 14 & 88 \\
\hline SD Negeri 2 Berangbang & 49,18 & 70 & 17 & 2 & 12 & 15 & 88 \\
\hline SD Negeri 3 Berangbang & 47,75 & 65 & 20 & 4 & 20 & 16 & 80 \\
\hline SD Negeri 4 Berangbang & 51,13 & 65 & 16 & 3 & 19 & 13 & 81 \\
\hline SD Negeri 5 Berangbang & 46,87 & 68 & 23 & 2 & 9 & 21 & 91 \\
\hline SD Negeri 1 Kaliakah & 49,26 & 65 & 27 & 5 & 19 & 22 & 81 \\
\hline SD Negeri 2 Kaliakah & 48,59 & 70 & 32 & 2 & 6 & 30 & 94 \\
\hline SD Negeri 3 Kaliakah & 46,44 & 65 & 25 & 4 & 16 & 21 & 84 \\
\hline SD Negeri 4 Kaliakah & 47,42 & 70 & 19 & 3 & 16 & 16 & 84 \\
\hline SD Negeri 5 Kaliakah & 49,4 & 60 & 10 & 3 & 30 & 7 & 70 \\
\hline
\end{tabular}




\begin{tabular}{ccccccccc}
\hline \multirow{2}{*}{ Nama Sekolah } & \multirow{2}{*}{$\begin{array}{c}\text { Rata-Rata } \\
\text { UAS }\end{array}$} & KKM & $\begin{array}{c}\text { Jumlah } \\
\text { Siswa }\end{array}$ & & \multicolumn{2}{c}{$\begin{array}{c}\text { Siswa yang } \\
\text { mencapai KKM }\end{array}$} & \multicolumn{2}{c}{$\begin{array}{c}\text { Siswa yang } \\
\text { belum mencapai } \\
\text { KKM }\end{array}$} \\
\cline { 5 - 9 } & Jumlah & & & 205 & 30 & 15 & 175 & 85 \\
\hline
\end{tabular}

Berdasarkan Tabel 01 dapat diketahui bahwa nilai rata-rata hasil belajar PKn siswa kelas V SD di Gugus VI Kecamatan Negara berada pada rentang nilai 46,44-51,13. Jika dikonversikan terhadap skala penilaian acuan patokan (PAP) (dalam Agung, 2014), Rentang nilai tersebut berada pada kategori sangat kurang. Hal ini menandakan bahwa nilai rata-rata UAS PKn siswa kelas V di Gugus VI Kecamatan Negara dapat diidentifikasikan terdapat masalah.

Berdasarkan permasalahan di atas, untuk meningkatkan sikap sosial dan hasil belajar PKn siswa yang masih rendah, diperlukan upaya yang inovatif dalam pembelajaran. Upaya yang dapat dilakukan adalah dengan menerapkan model-model pembelajaran kooperatif. Salah satu model pembelajaran kooperatif yang dianggap tepat untuk meningkatkan sikap sosial dan hasil belajar yaitu model pembelajaran kooperatif tipe Group Investigation berbantuan media Question Card.

Model pembelajaran group investigation merupakan pembelajaran dengan kelompok kecil untuk menuntun dan mendorong siswa dalam keterlibatan belajar. Group Investigation adalah model pembelajaran kooperatif yang menekankan pada partisipasi dan keaktifan siswa dalam kegiatan pembelajaran dan dalam pembelajaran siswa mempunyai kebebasan untuk mencari sendiri materi yang akan dipelajari melalui bahan-bahan yang tersedia. Menurut Mushoddik (2016) model pembelajaran Group Investigation merupakan tipe pembelajaran yang menekankan pada struktur khusus yang dirancang untuk mempengaruhi pola interaksi siswa dan memiliki tujuan untuk meningkatkan penguasaan akademik, meningkatkan kinerja siswa dalam tugas-tugas akademik, agar siswa dapat menerima teman-temannya yang mempunyai berbagai latar belakang, dan untuk mengembangkan keterampilan siswa. Keterampilan yang dimaksud antara lain berbagai tugas, aktif bertanya, menghargai pendapat orang lain, mau menjelaskan ide atau pendapat, bekerja dalam kelompok dan sebagainya.

Rusman (dalam Wiryarta, 2014) menyatakan bahwa implementasi model pembelajaran kooperatif tipe Group Investigation dalam pembelajaran, secara umum dibagi menjadi enam langkah yaitu sebagai berikut. 1) Memilih Topik, siswa memilih sub topik khusus di dalam suatu daerah masalah umum yang biasanya ditetapkan oleh guru. Selanjutnya siswa diorganisasikan menjadi dua sampai enam anggota tiap kelompok menjadi kelompokkelompok yang berorientasi tugas. Komposisi kelompok hendaknya heterogen secara akademis maupun etnis. 2) Perencanaan Kooperatif, siswa dan guru merencanakan prosedur pembelajaraan, tugas, dan tujuan khusus yang konsisten dengan sub topik yang telah dipilih pada tahap pertama. 3) Implementasi, siswa menerapkan rencana yang telah mereka kembangkan di dalam tahap kedua. Kegiatan pembelajaran hendaknya melibatkan ragam aktivitas mengarahkan siswa kepada jenis-jenis sumber belajar yang berbeda baik di dalam atau di luar sekolah. Guru secara ketat mengikuti kemajuan tiap kelompok dan menawarkan bantuan bila diperlukan. 4) Analisis Dan Sintesis, siswa menganalisis dan mensintesis informasi yang diperoleh pada tahap ketiga dan merencanakan bagaimana informasi tersebut diringkas dan disajikan dengan cara yang menarik sebagai bahan untuk dipresentasikan kepada seluruh kelas. 5) Presentasi Hasil Final, beberapa atau semua kelompok menyajikan hasil penyelidikannya dengan cara yang menarik kepada seluruh kelas, dengan tujuan agar siswa yang lain saling terlibat satu sama lain dalam pekerjaan mereka dan memperoleh perspektif luas pada topik itu. Presentasi dikoordinasikan oleh guru. 6) Evaluasi, dalam hal kelompok-kelompok mengenai aspek yang berbeda dari topik 
yang sama, siswa dan guru mengevaluasi tiap kontribusi kelompok terhadap kerja kelas sebagai suatu keseluruhan.

Rusman (dalam Rustina 2014) menyatakan beberapa keunggulan pembelajaran kooperatif tipe Group Investigation, yaitu: (1) Dapat dipakai untuk mengembangkan tanggung jawab dan kreatifitas siswa, baik secara perorangan maupun kelompok (2) Menghilangkan sifat egois, dapat meningkatkan kegemaran berteman tanpa memandang perbedan kemampuan, jenis kelamin, etnis, kelas sosial dan agama (3) Memberikan kesempatan bagi siswa untuk berkolaborasi dengan teman sebaya dalam dalam bentuk diskusi kelompok untuk memecahkan suatu masalah (4) Serta mengaktifkan siswa dalam proses pembelajaran yang diberikan guru sehingga dapat membangun pengetahuan siswa.

Untuk membuat pembelajaran agar semakin menarik maka salah satu cara yang dapat dilakukan yaitu dengan memadukan model pembelajaran dengan suatu media yang dapat meningkatkan semangat siswa dalam pembelajaran Menurut sardiman (dalam Yunita, 2014) Media adalah perantara atau pengantar pesan dari pengirim ke penerima pesan. Sejalan dengan pendapat Arsyad (dalam Yunita, 2014) menyatakan "media sebagai segala bentuk dan saluran yang digunakan untuk menyampaikan pesan atau informasi".. Berdasarkan pendapat para ahli diatas dapat simpulkan Media pembelajaran adalah suatu alat yang digunakan sebagai perantara untuk menyampaikan suatu pesan, atau informasi dan materi pembelajaran kepada siswa sehingga dapat mendorong terjadinya proses belajar yang disengaja, bertujuan, dan terkendali.

Question Card adalah suatu media yang dapat digunakan dalam pembelajaran. Media Question Card. Menurut Haejamto (dalam Ardani, dkk, 2014) Question card atau kartu soal merupakan media visual yang berupa kertas berukuran $10 \times 10$. Isi dari kartu ini yaitu sebagian berisi soal-soal tentang materi yang akan diajarkan. Penggunaan media kartu merupakan sarana yang fungsi utamanya sebagai alat bantu untuk melakukan kegiatan pembelajaran. Dengan media Question Card memungkinkan siswa belajar lebih rileks dalam kelompok dengan memainkan kartu soal, disamping menumbuhkan sikap sosial diantaranya percaya diri, tanggung jawab, kerjasama, persaingan sehat, dan keterlibatan belajar.

Dengan demikian tujuan dari penelitian ini adalah 1) Mengetahui pengaruh model pembelajaran kooperatif tipe Group Investigation berbantuan media Question Card terhadap sikap sosial pada siswa kelas V SD di Gugus VI Kecamatan Negara, 2) Mengetahui pengaruh model pembelajaran kooperatif tipe Group Investigation berbantuan media Question Card terhadap hasil belajar PKn pada siswa kelas V SD di Gugus VI Kecamatan Negara, 3) Mengetahui pengaruh secara simultan model pembelajaran kooperatif tipe Group Investigation berbantuan media Question Card terhadap sikap sosial dan hasil belajar PKn pada siswa kelas V SD di Gugus VI Kecamatan Negara.

\section{Metode}

Penelitian ini dilaksanakan pada semester 2 tahun ajaran 2018/2019 di kelas V SD Gugus VI Kecamatan Negara, Kabupaten Jembrana. Penelitian ini berlangsung dari bulan April-Mei 2019.

Penelitian ini menggunakan quasi eksperimen (Eksperimen Semu). Desain penelitian yang digunakan yaitu non equivalent post-test only control group design. Dalam penelitian ini yang ingin di uji keefektifan pendekatan model pembelajaran Group Investigation (GI) berbantuan media Question Card.

Rancangan penelitian ini yang digunakan adalah non equivalent post-test only control group design yaitu hanya menggunakan post-test yang dilakukan pada akhir penelitian variable model bebas yaitu model Group Investigation berbantuan media questio card dan variable terikat yaitu sikap sosial dan hasil belajar PKn. Pada rancangan ini, terdapat dua kelompok subjek, satu mendapat perlakuan (kelompok eksperimen) dan satu kelompok sebagai kontrol. Untruk kelompok eksperimen diberikan pembelajaran dengan menerapkan model pembelajaran Group Investigation (Gl) berbantuan media Question Card sedangkan untuk kelompok dibelajarkan secara konvensional. 
Populasi adalah sekumpulan objek dalam suatu penelitian yang memenuhi kriteria tertentu. Populasi pada penelitian ini adalah seluruh siswa kelas V SD Gugus VI Kecamatan Negara Tahun pelajaran 2018/2019. Jumlah populasi dalam penelitian ini adalah 10 SD dengan total siswa 205 orang. Selanjutnya dilakukan uji kesetaraan pada semua sekolah SD yang ada di gugus VI Kecamatan Negara. Data yang digunakan dalam uji kesetaraan adalah nilai ulangan tengah semester (UTS) ganjil mata pelajaran PKn kelas V. Uji kesetaraan ini menggunakan analisis Anava Satu Jalur. Hasil analisis dengan Anava Satu Jalur menunjukkan bahwa nilai UTS PKn kelima sekolah tersebut setara (sama).

Sugiyono (2015:118) menyatakan bahwa "sampel adalah bagian dari jumlah dan karakteristik yang dimiliki oleh populasi tersebut". Teknik yang digunakan dalam pengambilan sampel adalah simple random sampling atau sampel acak sederhana. Teknik random dilakukan dengan cara manual yaitu dengan sistem undian. Pengundian sampel ini dilakukan sebanyak dua kali, undian pertama dilakukan untuk menentukan 2 sampel yang akan digunakan untuk penelitian, kemudian undian kedua dilakukan untuk menentukan sampel yang akan dijadikan sebagai kelompok kontrol dan kelompok eksperimen.

Berdasarkan hasil random sampling dipreloleh sampel, yaitu kelas V SD Negeri 2 Kaliakah yang berjumlah 32 orang sebagai kelompok eksprimen dan SD Negeri 5 Berangbang yang berjumlah 23 orang sebagai kelompok kontrol.

Penelitian ini melibatkan dua variabel yaitu variabel bebas dan variabel terikat. Variabel bebas dalam penelitian ini yaitu Model Pembelajaran Group Investigation berbantuan media question card dan variabel terikat dalam penelitian ini adalah sikap sosial dan hasil belajar PKn.

Metode yang digunakan untuk mengumpulkan data dalam penelitian ini adalah metode kuesioner dan tes, dengan menggunakan tes obyektif. Kuesioner dan Tes obyektif digunakan pada saat post-test. Data yang telah dikumpulkan dianalisis dengan menggunakan statistik deskriptif dan statistik inferensial. Statistik deskriptif berfungsi untuk mengelompokkan data, memaparkan serta menyajikan hasil olahan. Statistik deskriptif yang digunakan dalam penelitian ini yaitu mean (rata-rata), standar deviasi dan varians. Sedangkan statistik inferensial berfungsi untuk menggeneralisasikan hasil penelitian yang dilakukan pada sampel bagi populasi. Statistik inferensial ini digunakan untuk menguji hipotesis melalui uji MANOVA yang diawali dengan analisis prasyarat yaitu uji normalitas sebaran data dan uji homogenitas varians.

\section{Hasil dan Pembahasan \\ Hasil}

Data dalam penelitian ini adalah skor sikap sosial dan hasil belajar PKn siswa kelas V yang dibelajarkan menggunakan model pembelajaran Group Investigation berbantuan media Question Card pada kelompok eksperimen dan model pembelajaran konvensional pada kelompok kontrol. Deskripsi hasil penelitian memaparkan dua hal pokok, yaitu deskripsi data hasil post-test kelompok eksperimen dan deskripsi data hasil post-test kelompok kontrol. Rekapitulasi perhitungan data hasil penelitian sikap sosial dan hasil belajar PKn dapat dilihat pada Tabel 2.

Tabel 2

Rekapitulasi Hasil Perhitungan Skor Sikap sosial dan Hasil Belajar PKn.

\begin{tabular}{lcccc}
\hline \multirow{2}{*}{ Statistik } & \multicolumn{2}{c}{ Kelompok Eksperim,en } & \multicolumn{2}{c}{ Kelompok Kontrol } \\
\cline { 2 - 5 } & Sikap Sosial & Hasil Belajar & Sikap Sosial & Hasil Belajar \\
\hline Jumlah Responden & 32 & 32 & 23 & 23 \\
\hline Mean & 111,16 & 24,5 & 89,96 & 16,43 \\
\hline Median & 114 & 25 & 92 & 16 \\
\hline Modus & 115 & 27 & 14,47 & 15 \\
\hline Standar Deviasi & 8,04 & 2,23 & 209,32 & 17,44 \\
\hline Varians & 64,65 & 4,68 & 67 & 8 \\
\hline Skor Minimal & 92 & 20 & 117 & 23 \\
\hline Skor Maksimal & 125 & 28 & & 18 \\
\hline
\end{tabular}


Berdasarkan hasil rekapitulasi data pada tabel di atas, maka dapat disimpulkan bahwa rata-rata sikap sosial dan hasil belajar Pkn siswa pada kelompok yang dibelajarkan dengan model Group Investigation berbantuan media Question Card lebih besar dari rata-rata sikap sosial dan hasil belajar PKn siswa yang dibelajarkan dengan pembelajaran konvensional.

Kemudian dilakukan uji hipotesis untuk mengetahui pengaruh dari model pembelajaran yang diterapkan. Namun sebelum dilakukan uji hipotesis, terlebih dahulu dilakukan uji prasyarat yaitu uji normalitas dan uji homogenitas varians. Berdasarkan uji prasyarat yang telah dilakukan diperoleh bahwa data sikap sosial dan hasil belajar PKn kelompok eksperimen dan kelompok kontrol berdistribusi normal dan varians kedua kelompok homogen. Selanjutnya pengujian hipotesis 1, 2, dan 3 dilakukan menggunakan MANOVA.

Normalitas sebaran data diuji dengan teknik Kolmogorov-Smirnov dengan bantuan SPSS 21.0 for windows. Hasil normalitas sebaran data dapat dilihat pada Tabel 3.

Tabel 3

Hasil Uji Normalitas

\begin{tabular}{|c|c|c|c|c|}
\hline \multirow{2}{*}{$\begin{array}{l}\text { Variabel yang } \\
\text { di ukur }\end{array}$} & \multirow{2}{*}{ Model Pembelajaran } & \multicolumn{3}{|c|}{ Kolmogorov-Smirnov $^{\mathrm{a}}$} \\
\hline & & Statistic & Df & Sig, \\
\hline \multirow[t]{3}{*}{ Sikap sosial } & Model Pembelajaran Kooperatif Tipe & & & \\
\hline & $\begin{array}{l}\text { Group Investigation Berbantuan Media } \\
\text { Question Card }\end{array}$ & 0,169 & 32 & 0,060 \\
\hline & Pembelajaran Konvensional & 0,088 & 23 & 0,200 \\
\hline \multirow[t]{2}{*}{$\begin{array}{l}\text { Hasil belajar } \\
\text { PKN }\end{array}$} & $\begin{array}{l}\text { Model Pembelajaran Kooperatif Tipe } \\
\text { Group Investigation Berbantuan Media } \\
\text { Question Card }\end{array}$ & 0,150 & 32 & 0,064 \\
\hline & Pembelajaran Konvensional & 0,148 & 23 & 0,200 \\
\hline
\end{tabular}

Berdasarkan Tabel 3. Di atas, menunjukkan bahwa statistik Kolmogorov-Smirnov memiliki angka signifikansi $>0,05$. Maka semua sebaran menurut Model Pembelajaran Kooperatif Tipe Group Investigation Berbantuan Media Question Card berdistribusi normal.

Uji homogenitas varians dengan bantuan SPSS 21.0 for windows menggunakan uji Box's $M$ menghasilkan angka signifikansi 0,103. Dengan menggunakan uji Levene's Test menghasilkan angka signifikansi 0,61 untuk sikap sosial dan angka signifikansi 0,81 untuk hasil belajar PKn. Hasil analisis dapat dilihat pada Tabel 4 dan Tabel 5.

Tabel 4

Hasil Analisis Uji Box's M

\begin{tabular}{cc}
\hline Box's $M$ & 6,241 \\
\hline $\mathrm{F}$ & 67,903 \\
\hline $\mathrm{df1}$ & 2 \\
\hline $\mathrm{df} 2$ & 0,062 \\
\hline Sig, & 0,000 \\
\hline
\end{tabular}

Tabel 5

Hasil Analisis Uji Levene's Test

\begin{tabular}{ccccc}
\hline & $F$ & df1 & df2 & Sig, \\
\hline Sikap sosial Siswa & 11,254 & 1 & 53 & 0,061 \\
\hline Hasil belajar PKN & 6,952 & 1 & 53 & 0,081 \\
\hline
\end{tabular}

Berdasarkan hasil analisis data di atas, angka signifikansi yang dihasilkan dari sikap sosial maupun hasil belajar PKN siswa secara bersama - sama maupun sendiri - sendiri yaitu > 0,05. Dengan demikian dapat disimpulkan analisis sikap sosial dan hasil belajar PKN siswa adalah homogen sehingga uji hipotesis menggunakan analisis MANOVA (Multivariate Analysis of Varians) dapat dilanjutkan.

Hasil perhitungan hipotesis 1 dengan menggunakan uji MANOVA berbantuan SPSS 21.0 for windows dapat dilihat pada Tabel 6 . Sebagai berikut.

Tabel 6

Hasil Uji Hipotesis Pertama Data Sikap Sosial Siswa 


\begin{tabular}{lrrrrrr}
\hline \multicolumn{2}{c}{ Sumber } & Dependent Variabel & df & Mean Square & F & Sig. \\
\hline $\begin{array}{l}\text { Model Pembelajaran } \\
\text { Berbantuan Media Question Card dan Pembelajaran }\end{array}$ & Sikap Sosial & 1 & 6014,170 & 48,229 & 0,000 \\
Konvensional & & & & & & \\
\hline
\end{tabular}

Berdasarkan hasil analisis dengan uji MANOVA data sikap sosial siswa yang dibelajarkan dengan Model Pembelajaran Kooperatif Tipe Group Investigation Berbantuan Media Question Card dan pembelajaran konvensional menghasilkan $\mathrm{F}$ sebesar 48,229, $\mathrm{df}=1$, dan $\mathrm{Sig}=0,000$ yang berarti signifikansi $<0,05$, maka hipotesis nol $\left(\mathrm{H}_{0}\right)$ ditolak, hipotesis alternatif $\left(\mathrm{H}_{1}\right)$ diterima.

Hasil perhitungan hipotesis 2 dengan menggunakan MANOVA berbantuan SPSS 21.0 for windows dapat dilihat pada Tabel 7. Sebagai berikut.

Tabel 7

Hasil Uji Hipotesis Kedua Data Hasil belajar PKN

\begin{tabular}{|c|c|c|c|c|c|}
\hline Sumber & Dependent Variabel & $d f$ & Mean Square & $F$ & Sig. \\
\hline $\begin{array}{l}\text { Model Pembelajaran Group Investigation } \\
\text { Berbantuan Media Question Card dan } \\
\text { Pembelajaran Konvensional }\end{array}$ & Hasil Belajar PKn & 1 & 870,457 & 85,807 & 0,000 \\
\hline
\end{tabular}

erdasarkan hasil analisis dengan uji MANOVA data hasil belajar PKN yang dibelajarkan dengan Model Pembelajaran Kooperatif Tipe Group Investigation Berbantuan Media Question Card dan pembelajaran konvensional menghasilkan $\mathrm{F}$ sebesar 85,807 , $\mathrm{df}=1$, dan Sig $=0,000$ yang berarti signifikansi $<0,05$ maka hipotesis nol $\left(\mathrm{H}_{0}\right)$ ditolak, hipotesis alternatif $\left(\mathrm{H}_{1}\right)$ diterima.

Hasil perhitungan hipotesis 3 dengan menggunakan MANOVA (Multivariate Analysis of Varians) berbantuan SPSS 21.0 for windows dapat dilihat pada Tabel 8. Sebagai berikut.

Tabel 8

Ringkasan Hasil Analisis Sikap sosial dan Hasil belajar PKN Siswa Kelas V SD dengan Uji MANOVA

\begin{tabular}{|c|c|c|c|c|c|c|}
\hline Effect & & Value & $\boldsymbol{F}$ & Hypothesis df & Error df & Sig, \\
\hline \multirow[t]{4}{*}{ Intercept } & Pillai's Trace & 0,991 & 2793,959 & 2,000 & 52,000 & 0,000 \\
\hline & Wilks' Lambda & 0,009 & 2793,959 & 2,000 & 52,000 & 0,000 \\
\hline & Hotelling's Trace & 107,460 & 2793,959 & 2,000 & 52,000 & 0,000 \\
\hline & Roy's Largest Root & 107,460 & 2793,959 & 2,000 & 52,000 & 0,000 \\
\hline \multirow[t]{4}{*}{$A$} & Pillai's Trace & 0,687 & 57,011 & 2,000 & 52,000 & 0,000 \\
\hline & Wilks' Lambda & 0,313 & 57,011 & 2,000 & 52,000 & 0,000 \\
\hline & Hotelling's Trace & 2,193 & 57,011 & 2,000 & 52,000 & 0,000 \\
\hline & Roy's Largest Root & 2,193 & 57,011 & 2,000 & 52,000 & 0,000 \\
\hline
\end{tabular}

Multivariate Test

Berdasarkan hasil analisis pada Tabel 8, nilai F Pillae Trace $(\mathrm{F}=2793,959)$, Wilks' Lambda ( $\mathrm{F}$ $=2793,959)$, Hotelling's Trace $(\mathrm{F}=2793,959)$, Roy's Largest Root $(\mathrm{F}=2793,959)$ yang seluruhnya memiliki signifikan 0,000 atau $<0,05$. Berdasarkan analisis data tersebut sehingga hipotesis nol $\left(\mathrm{H}_{0}\right)$ ditolah dan hipotesis alternatif $\left(\mathrm{H}_{1}\right)$ diterima.

Dengan demikian hasil hipotesis ketiga adalah terdapat perbedaan yang signifikan sikap sosial dan hasil belajar PKN siswa secara simultan antara siswa yang dibelajarkan dengan Model Pembelajaran Kooperatif Tipe Group Investigation Berbantuan Media Question Card dan dengan pembelajaran konvensional di SD Gugus VI Kecamatan Negara Tahun Pelajaran 2018/2019.

\section{Pembahasan}

Berdasarkan nilai uji hipotesis pertama diperoleh nilai koefisien $\mathrm{F}=48,229$ dengan signifikansi $(\mathrm{sig})=0,000(<0,05)$. Jika taraf signifikansi $<0,05$, maka hipotesis pertama diterima yang artinya terdapat pengaruh Model Pembelajaran Kooperatif Tipe Group Investigation Berbantuan Media Question Card terhadap sikap sosial siswa. Hasil analisis ini juga dibuktikan secara langsung melalui pengamatan ketika proses pembelajaran berlangsung, Pada kelas eksperimen yang 
diberikan perlakuan berupa Model Pembelajaran Kooperatif Tipe Group Investigation Berbantuan Media Question Card dalam mata pelajaran PKn membuat siswa lebih bersemangat dan membiasakan siswa untuk membaca, menggali informasi dan menemukan konsep dengan sendirinya. Siswa menjadi mandiri dan pemahaman siswa juga semakin meningkat karena dalam pembelajaran siswa mendengarkan dan mendapat pengalaman langsung serta membuat analisa sendiri terkait dengan materi yang diajarkan. Sementara pada kelas kontrol yang menggunakan pembelajaran konvensional siswa terlihat pasif dan siswa hanya menunggu penjelasan dari guru tanpa mau mencari sendiri tentang materi yang sedang diajarkan. Siswa tidak aktif dalam menjawab pertanyaan guru, karena siswa merasa jenuh untuk membaca materi pelajaran. Karena dari malasnya siswa mencari tahu tentang pelajaran yang disampaikan guru melalui membaca, itulah yang menyebabkan sikap sosial siswa pada kelas kontrol rendah.

Dalam mata pelajaran PKn Model Pembelajaran Kooperatif Tipe Group Investigation Berbantuan Media Question Card sangat tepat di terapkan, karena mata pelajaran PKn berhubungan erat dengan lingkungan sekitar kita terutama lingkungan sosial kita. Dengan diterapkannya model Pembelajaran Group Investigation Berbantuan Media Question Card pada mata pelajaran PKn terlihat bahwa kerjasama siswa semakin meningkat, siswa lebih bertanggung jawab menyelesaikan tugas kelompok, siswa mau saling membantu dalam memecahkan permasalahan dalam diskusi kelompok, Siswa yang memiliki perbedaan pengetahuan mampu saling mendorong satu samalain untuk berpartisipasi dan berprestasi, serta siswa yang kesehariannya hanya diam setelah dibelajarakan dengan pembelajaran Group Investigation Berbantuan Media Question Card kini mau dan mampu menyampaikan pendapatnya dalam diskusi untuk meningkatkan poin kelompok dan membuat kelompoknya menjadi lebih unggul. Hal tersebut menunjukkan bahwa model Group Investigation Berbantuan Media Question Card melatih dan mengajarkan siswa untuk bersosialisasi dan mengajarkan siswa tentang sikap yang baik dan benar.

Sejala dengan Elmubarok (2009:47) "sikap adalah suatu bentuk evaluasi perasaan dan kecenderungan potensial untuk bereaksi yang merupakan hasil interaksi antara komponen kognitif, afektif dan konatif yang saling bereaksi didalam memahami, merasakan dan berprilaku terhadap suatu objek". Dengan demikian dapat dikatan sikap adalah penjelmaan dari paradigma yang pada giliranya akan melahirkan nilai-nilai yang dianut seseorang.

Sikap yang dianut oleh banyak orang yang disebut sikap sosial. "Sikap sosial adalah sikap yang ada pada kelompok orang yang ditujukan pada suatu objek yang menjadi perhatian seluruh anggota kelompok tersebut" (Sarwono 2017:201). Menurut Virani, dkk (2016) "Sikap sosial adalah sikap yang menentukan cara individu untuk menghadapi individu lainnya dalam masyarakat terhadap objek-objek sosial yang ada". Teori tersebut didukung oleh penelitian yang dilakukan oleh Pranata,dkk tahun 2015 melakukan penelitian tentang perbedaan sikap sosial dan hasil belajar IPS siswa secara bersama-sama antara kelompok siswa yang mengikuti pembelajaran dengan menggunakan Model Pembelajaran Kooperatif tipe Group Investigation dan kelompok siswa yang mengikuti Model pembelajaran konvensional pada siswa kelas $\mathrm{V}$ SD gugus IV kecamatan Klungkung Tahun ajaran 2014/2015 ( $P<0,05)$.

Berdasarkan hasil analisis dan penelitian pendukung yang sesuai dengan penelitian ini, dapat disimpulkan bahwa Model Pembelajaran Kooperatif Tipe Group Investigation Berbantuan Media Question Card berpengaruh terdapat sikap sosial siswa Kelas V SD di Gugus VI Kecamatan Negara Tahun Pelajaran 2018/2019.

Berdasarkan hasil uji hipotesis kedua dalam penelitian ini, diperoleh nilai koefisien $\mathrm{F}=85,807$ dengan signifikansi $(\mathrm{sig})=0,000(>0,05)$. Jika taraf signifikansi $>0,05$, maka hipotesis kedua diterima yang artinya terdapat pengaruh Model Pembelajaran Kooperatif Tipe Group Investigation Berbantuan Media Question Card terhadap hasil belajar PKn siswa. Disamping Model Pembelajaran Kooperatif Tipe Group Investigation Berbantuan Media Question Card berpengaruh terhadap sikap sosial siswa juga berpengaruh terhadap hasil belajar PKN siswa. Hal ini dibuktikan secara langsung melalui pengamatan ketika proses pembelajaran berlangsung, Pada kelas ekperimen setelah diterapkan Model Pembelajaran Kooperatif Tipe Group Investigation Berbantuan Media Question Card terlihat perubahan pada siswa, melalui kegiatan pembelajaran hasil belajar siswa lebih meningkat, lebih aktif berinteraksi dengan teman dan gurunya, dalam 
mengerjakan tugas dari guru lebih percaya dengan apa yang diketahui karena siswa aktif dalam menggali pengetahuannya sendiri.

Secara teoritis menurut Oemar Hamalik (dalam Rusman 2017) yang menyatakan bahwa hasil belajar itu dapat terlihat dari terjadinya perubahan dari persepsi dan prilaku, termasuk juga perbaikan perilaku. Misalnya, pemuasan kebutuhan masyarakat dan pribadi secara utuh. Belajar merupakan proses yang kompeks dan terjadinya perubahan perilaku pada saat proses belajar diamati pada perubahan perilaku siswa setelah dilakukan penilaian.

Hasil penelitian ini di dukung oleh hasil penelitian yang dilakukan oleh Sastriawan,dkk pada tahun 2014 dan dari penelitian tersebut diperoleh terdapat perbedaan hasil belajar IPA yang signifikan antara siswa yang mengikuti pembelajaran dengan model pembelajaran kooperatif $\mathrm{Gl}$ (Group Investigation) dan siswa yang mengikuti pembelajaran dengan model pembelajaran konvensional pada siswa kelas V SD semester genap di Gugus XIII Kecamatan Buleleng Tahun Pelajaran 2012/2013.

Berdasarkan hasil analisis dan temuan lain yang sesuai dengan penelitian ini, dapat disimpulkan bahwa Model Pembelajaran Kooperatif Tipe Group Investigation Berbantuan Media Question Card berpengaruh terhadap hasil belajar PKN siswa pada siswa Kelas V SD di Gugus VI Kecamatan Negara Kabupaten Jembrana Tahun Pelajaran 2018/2019.

Berdasarkan hasil uji hipotesis ketiga dalam penelitian ini, diperoleh nilai $\mathrm{F}$ Pillae Trace (F= 2793,959), Wilks' Lambda ( $\mathrm{F}=2793,959)$, Hotelling's Trace ( $\mathrm{F}=2793,959)$, Roy's Largest Root $(\mathrm{F}$ $=2793,959$ ) yang seluruhnya memiliki signifikan 0,000 atau $<0,05$, maka hipotesis ke tiga diterima yaitu terdapat pengaruh secara simultan Model Pembelajaran Kooperatif Tipe Group Investigation Berbantuan Media Question Card terhadap sikap sosial dan hasil belajar PKn siswa.

Dari hasil analisis yang di lakukan dan dibuktikan melalui pengamatan dalam pembelajaran bahwa Model Pembelajaran Kooperatif Tipe Group Investigation Berbantuan Media Question Card berpengaruh terhadap sikap sosial dan hasil belajar PKN secara bersama-sama, Model Pembelajaran Kooperatif Tipe Group Investigation Berbantuan Media Question Card menekankan kepada proses keterlibatan siswa secara penuh untuk dapat menemukan pengetahuan baru melalui kegiatan percobaan.

Hasil penelitian ini didukung oleh Ariawan, dkk pada tahun 2016 dan dari penelitian tersebut diperoleh dari rata-rata hitung, diketahui rerata kelompok eksperimen adalah 10,50 dan rerata kelompok kontrol adalah 8,81. Hal ini berarti, rerata eksperimen > rerata kontrol. Berdasarkan hasil temuan tersebut, dapat disimpulkan bahwa penggunaan model kooperatif $t$ ipe Group Investigation berpengaruh terhadap hasil belajar IPA siswa kelas IV SD Negeri di Sidetapa tahun Pelajaran 2014/2015.

Berdasarkan hasil analisis dan temuan lain yang sesuai dengan penelitian ini, dapat disimpulkan bahwa Model Pembelajaran Kooperatif Tipe Group Investigation Berbantuan Media Question Card berpengaruh secara simulatan terdapat sikap sosial dan hasil belajar PKN siswa Kelas V SD di Gugus VI Kecamatan Negara Kabupaten Jembrana Tahun Pelajaran 2018/2019.

\section{Simpulan}

Berdasarkan paparan hasil penelitian dan pembahasan di atas dapat disimpulkan hasil penelitian ini yaitu 1) terdapat pengaruh yang signifikan model group investigation berbantuan media question card terhadap sikap sosial siswa kelas V SD gugus VI Kecamatan Negara, dengan memperoleh $\mathrm{F}$ sebesar 48,229, df =1, dan signifikansi $=0,000$ yang berarti signifikansi $<0,05$ yang artinya hipotesis nol ditolak dan hipotesis alternatif diterima. Dengan demikian model pembelajaran group investigation berbantuan media question card berpengaruh terhadap sikap sosial siswa, 2) terdapat pengaruh yang signifikan model group investigation berbantuan media question card terhadap hasil belajar PKn siswa kelas V SD gugus VI Kecamatan Negara, dengan memperoleh $\mathrm{F}$ sebesar 85,807 , df $=1$, dan signifikansi $=0,000$ yang berarti signifikansi $<0,05$ yang artinya hipotesis nol ditolak dan hipotesis alternatif diterima. Dengan demikian model pembelajaran group investigation berbantuan media question card berpengaruh terhadap hasil belajar PKn siswa, 3) terdapat pengaruh secara simultan model group investigation berbantuan media question card terhadap sikap sosial dan hasil belajar PKn siswa kelas V SD gugus $\mathrm{VI}$ Kecamatan Negara (F untuk Pillai's Trace, Wilks' Lamda, Hotelling's Trace dan Roy's Largest Root 
sebesar 2793,959 memiliki signifikansi lebih kecil dari 0,05). Dengan demikian dapat disimpulkan bahwa model group investigation berbantuan media question card berpengaruh secara signifikan terhadap sikap sosial dan hasil belajar PKn.

Berdasarkan hasil penelitian yang telah dilakukan, beberapa saran yang dapat diajukan guna peningkatan kualitas pembelajaran di SD adalah 1) bagi siswa diharapkan aktif dan bersungguhsungguh mengikuti pembelajaran PKn dengan Model Group Investigation berbantuan media Question Card sehingga mampu memberikan pengalaman yang sangat berharga dalam mengembangkan kemampuan secara optimal sehingga dapat meningkatkan sikap sosial dan hasil belajar PKn siswa, 2) bagi guru-guru di sekolah dasar agar lebih berinovasi dalam menerapkan model pembelajaran salah satunya menggunakan model pembelajaran group investigation berbantuan media question card pada mata pelajaran PKn atau mata pelajaran lainnya yang mendukung pembelajaran sehingga kemampuan profesional guru dapat meningkat, 3) bagi kepala sekolah hasil penelitian ini diharapkan dapat dijadikan sebagai acuan kepala sekolah untuk membimbing guru-guru dalam mengembangkan kebijakan-kebijakan sekolah sehingga kualitas pendidikan semakin meningkat, 4) bagi peneliti lain penelitian ini dapat dijadikan refrensi untuk melakukan penelitian pada variable yang sama ataupun variable yang berbeda dan penelitian ini dapat dijadikan informasi bagi peneliti lain dalam melakukan penelitian yang sejenis.

\section{Daftar Rujukan}

Ardani, N.P.M,dkk. 2014. "Pengaruh Model Kooperatif TGT Berbantuan Media Question Card Terhadap Hasil Belajar IPS Siswa Kelas V" Jurnal Mimbar PGSD Universitas Pendidikan Ganesha. Vol.2, No.1. Tersedia pada https://ejournal.undiksha.ac.id/index.php/JJPGSD/article/view/2275/1970. (Diakses pada 19 Januari 2019).

Ariawan, K.D., dkk. 2016. "Pengaruh Model Pembelajaran Kooperatif Tipe Group Investigation Berbasis Media Lingkungan Terhadap Hasil Belajar IPA Siswa Kelas IV di Desa Sidetapa”. Journal Pendidikan Guru sekolah Dasar fakultas ilmu Pendidikan Universitas Pendidikan Ganesha. Vol.4, No.1. Tersedia pada https://ejournal.undiksha.ac.id/index.php/JJPGSD/article/view/6609. (Diakses pada 31 Januari 2019).

Elmubarok, Zaim. 2009. Membumikan Pendidikan Nilai. Bandung: Alfabeta.

Mushoddik, dkk.2016. "Pengaruh Model Pembelajaran Group Investigation Terhadap Kemampuan Berpikir Kritis Siswa MAN 6 Jakarta". Tersedia pada http://jurnalnasional.ump.ac.id/index.php/GeoEdukasi/index. (Diakses pada 12 Juni 2019).

Peraturan Menteri Pendidikan Nasional Republik Indonesia Nomor 22 Tahun 2006 Tentang Standar Isi. 2006. Jakarta: Menteri Pendidikan Nasional.

Pranata, Elga, dkk. 2015. "Pengaruh Model Pembelajaran Kooperatif Tipe Group Investigation Terhadap Sikap Sosial dan Hasil Belajar Siswa". Journal Pendidikan Guru sekolah Dasar fakultas ilmu Pendidikan Universitas Pendidikan Ganesha. Vol.3,No.1. Tersedia pada https://ejournal.undiksha.ac.id/index.php/JJPGSD/article/view/5808. (Diakses pada 19 Januari 2019).

Renda, Ndara Tanggu \& Eka Widiastini. 2017. Pembelajaraan PPKn SD. Singaraja: Jurusan Pendidikan Guru Sekolah Dasar Fakultas Ilmu Pendidikan Universitas Pendidikan Ganesha.

Rusman. 2017. Belajar \& Pembelajaran Berientasi Standar Proses Pendidikan. Jakarta: Kencana.

Rustina, S. Pt. Bagus, Dkk. 2014. Pengaruh Model Pembelajaran Kooperatif Tipe Group Investigation Berbantuan Media Konkret Terhadap Hasil Belajar IPA Kelas V Sd Gugus II 
Tampaksiring" E-Journal Mimbar PGSD Universitas Pendidikan Ganesha Jurusan PGSD Vol: 2 No: $1 . \quad$ Tersedia pada https://ejournal.undiksha.ac.id/index.php/JJPGSD/article/view/1916/1665. (Diakses pada 1 April 2019).

Sarwono, Sarlito W. 2017. Pengantar Psikologi Umum. Jakarta: Rajawali Pers.

Sastriawan, I Gusti Nyoman, dkk. 2014. "Pengaruh Model Pembelajaran Kooperatif Group Investigation Terhadap Hasil Belajar Ipa Siswa Kelas V Di Gugus XIII Kecamatan Buleleng Tahun Pelajaran 2012/2013". e-Journal Mimbar PGSD Universitas Pendidikan Ganesha

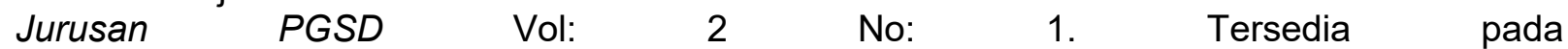
https://ejournal.undiksha.ac.id/index.php/JJPGSD/article/view/2011/1752. (Diakses pada 1 April 2019).

Sugiyono. 2015. Metode Penelitian Pendidikan. Bandung: Alfabeta.

Undang-Undang Republik Indonesia No.20 Tahun 2003 Tentang Sistem Pendidikan Nasional. 2007. Jakarta: Sinar Grafika.

Virani, Ida Ayu Dewi. 2016. "Deskripsi Sikap Sosial Siswa Kelas IV Sd Negeri 4 Penarukan Kecamatan Buleleng Kabupaten Buleleng". Journal Pendidikan Guru sekolah Dasar Fakultas IImu Pendidikan Universitas Pendidikan Ganesha. Vol.4, No,1. Tersedia pada https://ejournal.undiksha.ac.id/index.php/JJPGSD/article/view/7699. (Diakses pada 20 Januari 2019).

Wiryarta, Nyoman Saka, dkk. 2014. "Model Pembelajaran Kooperatif Tipe Group Investigation Berbasis Penilaian Proyek Berpengaruh Terhadap Hasil Belajar IPA Siswa Kelas V Sd Gugus Srikandi Denpasar Timur" .e-Journal Mimbar PGSD Universitas Pendidikan Ganesha Jurusan PGSD $\quad$ Vol: $\quad 2 \quad$ No: $1 . \quad 10$ Tersedia https://ejournal.undiksha.ac.id/index.php/JJPGSD/article/view/1949/1696 (Diakses pada 1 April 2019).

Yunita, A.A.Ayu Nevi Yuli, dkk. 2014. "Pengaruh Model Pembelajaran Kooperatif Tipe Group Investigation Berbantuan Media Gambar Terhadap Hasil Belajar Ipa Siswa Kelas V Sdn 21 Dauh Puri". Jurnal Mimbar PGSD Universitas Pendidikan Ganesha Jurusan PGSD (Vol: 2 No: 1. Tersedia pada https://ejournal.undiksha.ac.id/index.php/JJPGSD/article/view/2232/1931. (Diakses pada 1 April 2019). 